\title{
Assessment of innovation activity in the countries of the world
}

\author{
Dmitry Morkovkin ${ }^{1}$, Dmitry Lopatkin ${ }^{2}$, Manuchehr Sadriddinov ${ }^{3}$, Tatiana Shushunova ${ }^{2}$, \\ Arthur Gibadullin", ${ }^{4, *}$ and Olga Golikova ${ }^{4}$ \\ ${ }^{1}$ Financial University under the Government of the Russian Federation, 49, Leningradsky avenue, \\ Moscow, 125993, Russian Federation \\ ${ }^{2}$ Mendeleev University of Chemical Technology of Russia, 9, Miusskaya sq., Moscow, 125047, \\ Russian Federation \\ ${ }^{3}$ Tajik State Finance and Economics University, 64/14, Nakhimova Street, Dushanbe, 734067, \\ Republic of Tajikistan \\ ${ }^{4}$ State University of Management, 99, Ryazan Avenue, Moscow, 109542, Russian Federation
}

\begin{abstract}
The purpose of the study is to evaluate innovation activity in the countries of the world. Based on the use of statistical, comparative, systemic and logical methods, an analysis of indicators of innovative activity was carried out, as a result of which it was concluded that Russia lags behind other countries in terms of innovative development. Using methods of economic and factor analysis, a factor model was formed in the work, which included groups of global, national, industry and corporate factors, the management of which will ensure a sustainable transition to innovative technologies of the national economy. In the ending of the study the main conclusions and results of the work are presented.
\end{abstract}

\section{Introduction}

Today, the countries of the world are actualizing the transition from one technological structure to another, that is, the use of more and more new and advanced technologies in order to facilitate the work of workers, reduce production costs, preserve natural resources for future generations and ensure sustainable growth for the economy. Therefore, for example, in Russia and the world, these issues are associated with the transition to innovative technologies [1-4]. This issue is being worked out at the state, regional, industry and corporate levels. Institutions and communities have been formed that search for solutions to the goals and objectives [5].

In the Russia, this issue is being raised at the state level, concepts and programs are being developed that should be implemented at the corporate level, taking into account the requirements of federal laws and regulations [6-7]. In other countries of the world, questions of innovative development are initiated at the level of companies or transnational corporations that create their own research centers, laboratories, research institutes, etc.,

* Corresponding author: 11117899@mail.ru 
that is, they try to increase the competitiveness of their products in the domestic and foreign markets [8].

Researchers believe that the positive experience of foreign countries should be adopted by the Russia in order to increase the economic efficiency of industries and enterprises. Thus, the authors of the study should assess the level of innovative development of the world and determine the factors affecting innovation.

\section{Materials and methods}

The goal is to assess R\&D in Russia and the countries of the world and to identify factors holding back development. The research objectives are as follows:

- assess the level of innovation in Russia and countries of the world;

- offer recommendations for managing innovation.

The research used scientific methods that allowed solving the goal and objectives.

\section{Results}

The development of science providing new technologies began at the end of the last century, when completely new industries began to be created, individual business processes and business units were automated, and the transition to innovative and digital technologies was carried out. However, hotel countries have become leaders in innovation and have already embarked on a qualitatively new path of development [9-11].

In our study, we decided to analyze the Russia and individual countries of the world in terms of R\&D expenditures, sources of financing for $R \& D$ and innovative activity. Consider the national cost of R\&D to GDP (figure 1) [12].

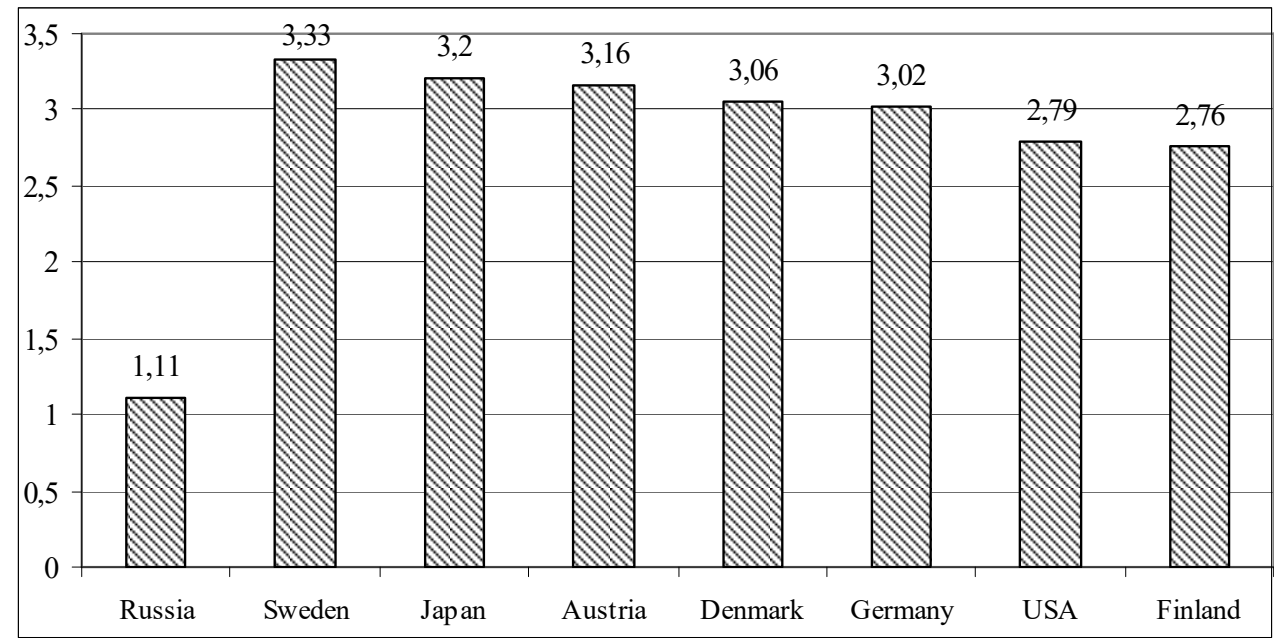

Fig 1. National R\&D expenditures as a percentage of gross domestic products in 2017.

It can be seen from the figure that Sweden, Japan and Austria are the leaders in national R\&D expenditures, while in the USA this indicator is $2.79 \%$, and in the Russia $-1.11 \%$. Thus, we can conclude that small states located in Europe, many times more direct investments in research and development than the Russia.

Next, we will analyze the sources of R\&D funding in these countries (figure 2) [12]. 


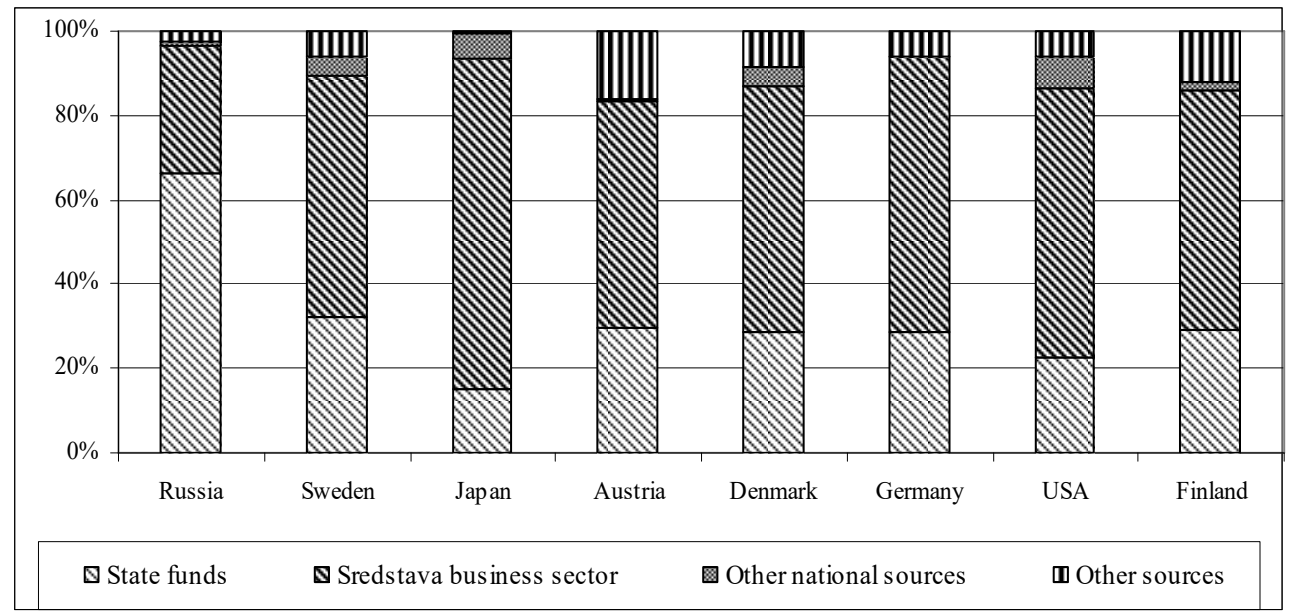

Fig. 2. Sources of R\&D financing in 2017 , as a percentage.

The figure shows that in the countries of the world most of the R\&D is financed by the business sector, and in the Russia by the public sector. At the same time, the second source of financing in the countries of the world is state funds, and in the Russia - funds from the business sector. A similar situation is obvious, since in the Russia the development of innovation is carried out at the state level, and in the countries of the world, these issues are addressed by entrepreneurial structures whose activities were aimed at improving goods and conquering new markets for goods and services [13-16].

Based on information on the amount of financing and sources of financing, it is advisable to consider the level of innovative activity of organizations in the countries of the world (figure 3) [12].

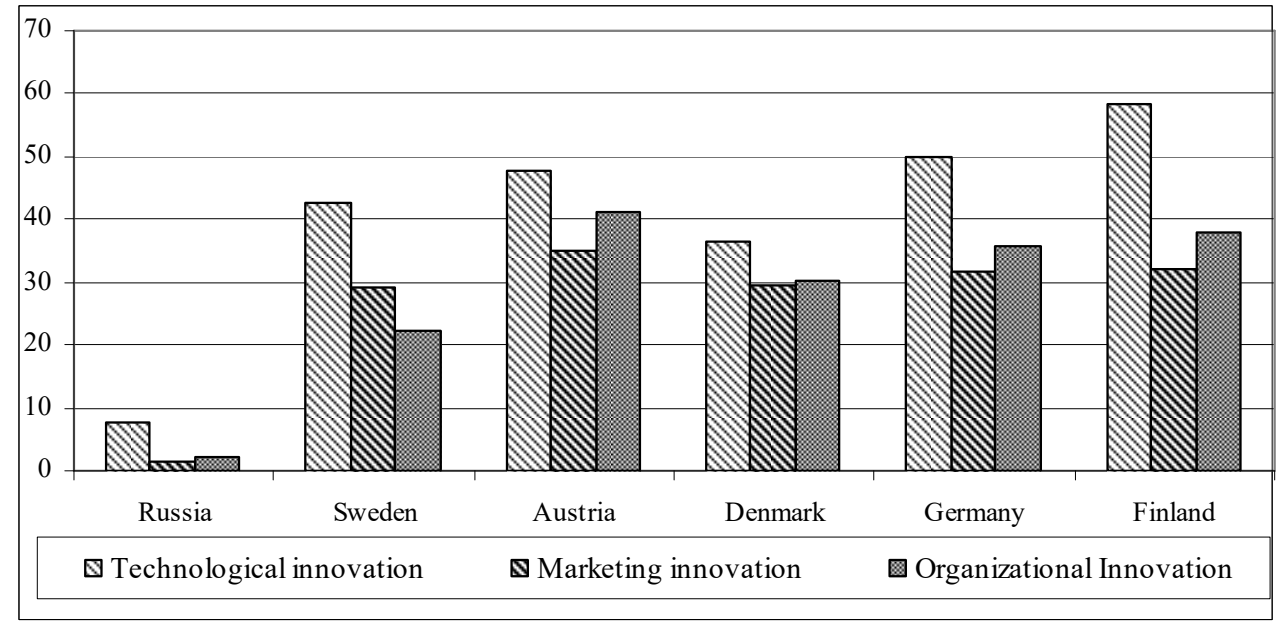

Fig. 3. Innovative activity of the organization in 2017 , as a percentage.

The figure shows that a high level of innovation is observed in Finland and Germany, while in these countries the level of technological innovation reaches 58\% and 50\%, respectively, indicating a transition to a qualitatively new path of technological production. In Austria, Sweden and Denmark, these indicators are also at a high level, however, in the Russia it does not exceed $8 \%$, which indicates the absence of any qualitative changes. Marketing innovations in all countries of the world make up an average of $30 \%$, in Russia 
they do not exceed $2 \%$, and organizational innovations $-2.3 \%$, when the world average is $30 \%[12,17-19]$.

Thus, despite the fact that R\&D financing in the Russia is $1.1 \%$ of GDP, the level of innovation activity is ten times less than in developed countries [12, 20]. Of course, this situation not only reduces the development of the economy, but also reduces the flow of investment in the economy, the competitiveness of industries and products, reduces the business activity of enterprises and more.

\section{Discussions}

Because of the assessment, the level of science and innovation in Russia was determined, which is lower than in developed countries, and therefore, it is advisable to identify the problems that hinder innovation in Russia. It is advisable to divide factors that negatively affect innovation activity into world, national, industry and corporate ones and present them in the form of the following scheme (figure 4) [21-23].

\begin{tabular}{|c|c|}
\hline $\begin{array}{l}\text { World factors: } \\
\text { 1. The availability of new } \\
\text { technologies; } \\
\text { 2. The level of development of } \\
\text { innovative technologies; } \\
\text { 3. The level of global demand for } \\
\text { specific innovations; } \\
\text { 4. The level of development of the } \\
\text { institutional environment }\end{array}$ & $\begin{array}{l}\text { National factors: } \\
\text { 1. The level of need for innovation; } \\
\text { 2. The level of readiness of the } \\
\text { economy for innovation and } \\
\text { digitalization; } \\
\text { 3. Investment attractiveness; } \\
\text { 4. The share of investment in } \\
\text { research and development; } \\
\text { 5. Availability of appropriate } \\
\text { infrastructure }\end{array}$ \\
\hline \multicolumn{2}{|c|}{ Factors Affecting Innovation } \\
\hline $\begin{array}{l}\text { Industry factors: } \\
\text { 1. The level of innovation and } \\
\text { digital development; } \\
\text { 2. The availability of appropriate } \\
\text { strategies and programs; } \\
\text { 3. Production readiness; } \\
\text { 4. The presence of specialized } \\
\text { scientific and educational centers }\end{array}$ & $\begin{array}{l}\text { Corporate factors: } \\
\text { 1. The availability of relevant } \\
\text { personnel; } \\
\text { 2. The level of investment } \\
\text { attractiveness of the company; } \\
\text { 3. The level of need for innovation; } \\
\text { 4. Volumes of R\&D financing; } \\
\text { 5. The level of interaction within the } \\
\text { industry }\end{array}$ \\
\hline
\end{tabular}

Fig. 4. Factors affecting the innovative activity of the Russia.

From the presented scheme, it is clear that groups of factors related to the scientific, technical, personnel, financial, regulatory, industrial and organizational component, affect innovation activity.

In order to achieve a positive effect in the development of innovative activity, it is advisable at each level to develop our own lines of development or interaction, which will already ensure not only a qualitative transition, but also a quantitative transformation of decisions made at the national or industry level. One of the following components is the management of these factors and the reduction of their negative impact on innovation activity at the state, industry and corporate levels. 
Thus, in order to increase innovation activity to global indicators, it is necessary to manage and regulate these factors at each structural level.

\section{Conclusion}

The study was devoted to issues aimed at studying science and innovation in Russia. The indicators used for the analysis are related to the volume of national R\&D expenditures, sources of R\&D financing and the level of innovative activity of organizations. Because of the assessment, it was revealed that the share of R\&D expenditures is $3.3 \%$ of GDP in Sweden, $3.2 \%$ of GDP in Japan, $2.79 \%$ of GDP in the United States, and in the Russia, this figure was $1.1 \%$ of GDP. The sources of R\&D financing in developed countries are the business sector, and in Russia, it is the state budget. It is proved in the work that this situation is due to private business initiatives in developed countries in order to increase production efficiency, and in the Russia - the state. The following indicator examined the level of innovation activity, which in developed countries is $50-60 \%$, and in the Russia, it does not exceed $8 \%$. For the development of innovation in work, the problems that hinder innovation were identified, because of which a factor model of development support was formed.

\section{References}

1. D.E. Sorokin, Economy of region, 1 (1), 17-29 (2015). DOI: 10.17059/2015-1-2

2. E.V. Ganina, N.M. Malyugina, R.I. Polyakova, E.A. Fedorova, O.N. Bykova, International Journal of Engineering and Advanced Technology, 9(1), 5565-5569 (2019) DOI: 10.35940/ijeat.A2128.109119

3. A. Gibadullin, V. Pulyaeva, E3S Web of Conferences, 114, 02002 (2019) https://doi.org/10.1051/e3sconf/201911402002

4. V.Yu. Linnik, Yu.N. Linnik, Upravlenie, 7, 1, $40-49$ (2019) DOI: 10.26425/23093633-2019-1-40-49

5. Z.K. Omarova, S. Ivanovichnikishov, A.S. Ellaryan, A.D. Bobryshev, E.Y. Kamchatova, Journal of Advanced Research in Dynamical and Control Systems, 10, S10, 581-586 (2019) DOI: 10.5373/JARDCS/V11SP10/20192845

6. D.E. Morkovkin, Ch.V. Kerimova, O.I. Dontsova, A.A. Gibadullin, Journal of Physics: Conference Series, 1399, 033042 (2019) DOI:10.1088/17426596/1399/3/033042

7. V.N. Zakharov, V.Y. Linnik, Y.N. Linnik, A.B. Zhabin, Mining Informational and Analytical Bulletin, 5, 5-12 (2019) DOI: 10.25018/0236-1493-2019-05-0-5-12

8. V.I. Tinyakova, V.V. Davnis, E.V. Miroshnikov, M.A. Chervontseva, I.Y. Proskurina, International Journal of Engineer-ing and Advanced Technology, 8, 6, 2, 1107-1111 (2019) DOI: 10.35940/ijeat.F1327.0886S219

9. D.S. Lopatkin, T.N. Shushunova, G.E. Shaldina, A.A. Gibadullin, I.L.Smirnova, Journal of Physics: Conference Series, 1399, 033061 (2019), DOI:10.1088/17426596/1399/3/033061

10. Y.N. Linnik, V.Y. Linnik, A.B. Zhabin, A.V. Polyakov, Mining Informational and Analytical Bulletin, 8, 33-41 (2019) DOI: 10.25018/0236-1493-2019-08-0-33-41

11. S.V. Bryukhovetskaya, K.A. Artamonova, A.A. Gibadullin, S.A. Ilminskaya, Z.M. Kurbonova, IOP Conference Series: Earth and Environmental Science, 421, 042018 (2020) DOI: 10.1088/1755-1315/421/3/042018 
12. Russian statistical yearbook 2018 (Moscow: Rosstat) 694

13. S.A. Tolkachev, A.A. Bykov, D.E. Morkovkin, O.I. Borisov, A.V. Gavrilin, IOP Conference Series: Earth and Environmental Science, 421, 032041 (2020) DOI: 10.1088/1755-1315/421/3/032041

14. A. Sozontov, M. Ivanova, A. Gibadullin, E3S Web of Conferences, 114, 01009 (2019) https://doi.org/10.1051/e3sconf/201911402002

15. E.V. Kulyasova, N.S. Kulyasov, A.Yu. Puchkov, Journal of Physics: Conference Series, 1260, 032024 (2019) DOI: 10.1088/1742-6596/1260/3/032024

16. I.A. Ivanova, V.N. Pulyaeva, L.V. Vlasenko, A.A. Gibadullin, M.I. Sadriddinov, Journal of Physics: Conference Series, 1399, 033038 (2019) DOI:10.1088/17426596/1399/3/033038

17. V.V. Davnis, V.I. Tinyakova, V.A. Fetisov, M.A. Chervontseva, S.I. Oparina, International Journal of Recent Technology and Engineering, 8, 3, 254-260 (2019) DOI: 10.35940/ijrte.C1059.1083S19

18. V.N. Zakharov, V.Y. Linnik, Y.N. Linnik, E.A. Averin, Eurasian Mining, 1, 40-42 (2019) DOI: 10.17580/em.2019.01.10

19. D.I. Zimnukhova, G.A. Zubkova, D.E. Morkovkin, P.V. Stroev, A.A. Gibadullin, Journal of Physics: Conference Series, 1399, 033097 (2019), DOI:10.1088/17426596/1399/3/033097

20. J.V. Gnezdova, E.N. Rudakova, O.P. Zvyagintseva, Studies in Systems, Decision and Control, 169, 211-218 (2019) DOI: 10.1007/978-3-319-94310-7_21

21. I.A. Ivanova, V.N. Pulyaeva, L.V. Vlasenko, A.A. Gibadullin, B.G. Safarov, IOP Conference Series: Earth and Environmental Science, 421, 032039 (2020) DOI: $10.1088 / 1755-1315 / 421 / 3 / 032039$

22. A.A. Gibadullin, M.I. Sadriddinov, Z.M. Kurbonova, Yu.N. Shedko, V.V. Shamraeva, IOP Conference Series: Earth and Environmental Science, 421, 032051 (2020) DOI: 10.1088/1755-1315/421/3/032051

23. D.E. Morkovkin, Sententia. European Journal of Humanities and Social Sciences, 1, 41-47 (2019) DOI: 10.25136/1339-3057.2019.1.26990 